\title{
Fresh and post thaw quality characteristics of Holstein Friesian bull semen maintained at semen production unit Quetta Balochistan, Pakistan
}

\author{
Abdul Hakeem Baloch ${ }^{1}$, Hamzo Khan Kunbhar ${ }^{2 *}$, Muhammad Ismail \\ Memon $^{2}$, Syed Muhammad Sharif ${ }^{1}$, Raiz Ahmed Leghari ${ }^{2}$, Huma \\ Rizwana $^{2}$ and Zahid Iqbal Rajput ${ }^{3}$ \\ 1. Veterinary officer, Department of Livestock, Government of Balochistan-Pakistan \\ 2. Faculty of Animal Husbandry and Veterinary Sciences, Sindh Agriculture University, Tandojam-Pakistan \\ 3. Shaheed Benazir Bhutto University of Veterinary and Animal Sciences, Sakrand Sindh-Pakistan \\ *Corresponding author's email: drkunbhar@gmail.com
}

Citation

Abdul Hakeem Baloch, Hamzo Khan Kunbhar, Muhammad Ismail Memon, Syed Muhammad Sharif, Raiz

Ahmed Leghari, Huma Rizwana, Zahid Iqbal Rajput. Fresh and post thaw quality characteristics of Holstein Friesian bull semen maintained at semen production unit Quetta Balochistan, Pakistan. Pure and Applied Biology. Vol. 8, Issue 1, pp780-789. http://dx.doi.org/10.19045/bspab.2019.80020

\begin{tabular}{llll}
\hline \hline Received: 02/11/2018 & Revised: 19/01/2019 & Accepted: 21/01/2019 & Online First: 7/02/2019 \\
\hline
\end{tabular}

\section{Abstract}

The study was conducted to determine the quality characteristics of fresh and post-thaw semen of Holstein Friesian bull, maintained at Semen Production Unit, Quetta Baluchistan, Pakistan. The semen were evaluated for volume, $\mathrm{pH}$, mass activity, sperm concentration, sperm motility and integrity of sperm cell membrane. The semen qualifying these criteria were processed for freezing. The frozen semen after thawing was assessed for progressive linear motility and intact cell membrane. The mean ejaculate volume of semen was recorded as $6.93,6.59$ and $6.61 \mathrm{ml}$, $\mathrm{pH} ; 6.58,6.59$ and 6.61 , mass activity of sperms $3.87,3.75$ and 3.5 and sperm concentration $1349.12 \times 10^{6}, 1509.37 \times 10^{6}$ and $1364.37 \times 10^{6} / \mathrm{ml}$ during the month of May, June and July respectively. The color of semen was not consistent pattern, it varied as creamy white and milky white. The motility of fresh and post thaw semen was assessed as 73.9 vs $48.75 \% ; 75$ vs. $53.75 \%$; 75 vs. $53.12 \%$ for the month of May, June and July respectively. The membrane integrity of fresh semen samples over a period of three month were $58.37 \%$ against post-thaw membrane integrity of $44.79 \%$. It was concluded that the semen of Holstein Friesian bull tolerates freezing and thawing stress and maintained reasonable good fertility. The summer season has no significant adverse effect on quality of semen.

Keywords: Bull; Fresh; Holstein Friesian; Post-thaw; Quality; Semen

\section{Introduction}

Artificial insemination is one of the most important biological technique applied for genetic improvement of the herd. Few selected males produce enough sperms to inseminate thousands of females in a year. The number of bulls required for breeding purpose, greatly less and consequently, the quality of bulls became a matter of vital importance [1]. Artificial insemination (AI) is now being widely used nearly in all cattle and buffaloes breeding countries. To achieving higher percentage of conception with artificial insemination, it is essential to improve the techniques of insemination and quality of diluted semen $[2,3]$. The fertility 
of spermatozoa, depends not only on the initial quality of semen, but also on subsequently laboratory process of semen dilution, chilling, freezing, storage and transportation, finally thawing for insemination invariably resulted in reduction of the viability and fertilizing capacity of spermatozoa [4].

The importance of breeding program is to identify genetically superior breeding bulls and to maximize the number of offspring conceived with frozen semen through artificial insemination (AI) [3]. Short term storage of semen may be satisfactory used for 3 to 4 days to meet day-to-day requirements of AI centers. However; it is difficult to maintain its fertility for a long time period. Increasing demand of importance of progeny testing, became evident of the development of new methods of semen preservation that could be beneficial for existing AI industry [4]. The fertilizing ability of spermatozoa is affected due to thawing temperature and duration. The change in temperature of freezing and thawing of semen, reduces the motile spermatozoa. A sufficient number of spermatozoa may die during process of freezing and thawing and adversely affecting the fertilizing ability of stored semen. Hence there was a great need to evaluate the semen for its fertility after freezing and thawing. This study therefore was planned to investigate the effect of freezing and thawing on the quality characteristics of sperms after thawing the semen of Holstein Friesian bull.

\section{Materials and methods}

\section{Management of experimental animals}

Four Holstein Friesian bulls of an age of three years and an average body weight of $450 \mathrm{~kg}$ were selected and housed at Semen Production Unit, Quetta Baluchistan, Pakistan. Green fodder (40 kg), wheat straw $(6-10 \mathrm{~kg})$ and concentrate mixture $(5 \mathrm{~kg})$ (oil seed cake + wheat bran) were fed to animals. The clean water were provided at ad-libitum. Regular vaccination against foot and mouth disease and deworming were under taken as per scheduled.

\section{Preparation and sterilization of equipment}

All the equipment and materials used for semen collection, evaluation and processing were cleaned with distilled water and sterilized in autoclave at temperature of $121{ }^{\circ} \mathrm{C}$ for 15 minutes at 15 pound pressure [5].

Preparation of bulls for semen collection Semen donor bulls were washed and cleaned before the arrival at the collection area. Washing of preputial sheath with normal saline solution was done to avoid contamination of the semen. The teaser bulls were also washed and cleaned properly. Dry towel/tissue papers were used to remove water from the preputial area.

\section{Semen collection}

Semen was collected with artificial-vagina technique, for the period of 12 weeks. Appropriate precautionary measures were adopted to avoid contamination of samples. The bulls were stimulated sexually and allowed two false mount before actual true mount.

\section{Semen evaluation}

Immediately after collection the semen samples were transferred in to the water bath, kept at $37{ }^{\circ} \mathrm{C}$ and evaluated for volume, color, $\mathrm{pH}$, sperm concentration, mass activity, sperm motility and progressive motility percentage of spermatozoa. Semen samples having grade of++mass activity and more than 60 percent progressive motility of spermatozoa were considered for further evaluation.

\section{Assessment of fresh semen samples Appearance}

Each fresh semen sample was assessed with naked eyes. Any unusual things such as blood, dis-coloration, dirt, dust and debris material was noted.

\section{Color}

Color of semen was judged with naked eye appearance and recorded as watery, milky white, yellowish white and creamy white.

\section{Volume}

Semen volume was measured directly from graduated collecting tube and recorded in $\mathrm{ml}$. 
pH

The $\mathrm{pH}$ of semen was recorded by using digital $\mathrm{pH}$ meter.

\section{Mass activity}

The mass activity was evaluated in a drop of fresh undiluted semen, placed on a prewarmed slide stage without cover-slip at low magnification (100x) and scored as 14 scales.

\section{Sperm motility}

The sperm motility before freezing (fresh semen) and after thawing was determined by placing one drop of diluted semen on a clean pre-warmed slide, covered with cover slip and examined at magnification of $400 x$ under light microscope. Sperm motility was scored on the basis of the percentage of spermatozoa moving straight forward direction in the field of microscope were recorded and expressed in percentage.

\section{Sperm concentration}

It was measured by Hemocytometer [6].

Assessment of membrane integrity (ORT)

The fresh semen sample was used for osmotic resistance test (ORT) [7].

\section{Extension of semen}

Each semen sample was diluted with Tris based extender. Semen was diluted in cold cabinet by brining both the semen and extender at same temperature to prevent from cold shock. Rate of dilution was based on initial sperm concentration observed and adjusted to have 20 million spermatozoa per straw (Table 1).

Table 1. Composition of tris-egg yolk extender

\begin{tabular}{|l|l|}
\hline Ingredients & Quantity \\
\hline Tris (hydroxymethyl-amino-methane) & $3.81 \mathrm{~g}$ \\
\hline D fructose & $1.25 \mathrm{~g}$ \\
\hline Citric acid & $1.97 \mathrm{~g}$ \\
\hline Glycerol & $7 \mathrm{ml}$ \\
\hline Egg yolk & $20 \mathrm{ml}$ \\
\hline Penicillin & $1000 \mathrm{iu}$ \\
\hline Streptomycin & $1.00 \mathrm{mg} / \mathrm{ml}$ \\
\hline Distilled water & $100 \mathrm{ml}$ \\
\hline
\end{tabular}

Source: Samad (1985) [8].

\section{Equilibration time}

Diluted semen was allowed to equilibrate in cold cabinet to reach at $5{ }^{\circ} \mathrm{C}$ for $5 \mathrm{hrs}$.

\section{Filling of straw}

The filling of straws were carried out with the help of manual suction machine in 0.5 $\mathrm{ml}$ straw. Sealing of the open end of the straw was done with polyvinyl chloride powder.

\section{Freezing of semen straw}

Freezing of semen straws were carried out by holding straws in liquid nitrogen vapors at $5 \mathrm{~cm}$ above the surface of liquid nitrogen for 5 minute. Then straws were plunged into liquid nitrogen $\left(-196{ }^{\circ} \mathrm{C}\right)$. The frozen semen was stored in liquid nitrogen for 24 hours and then assessed for post thaw quality.

\section{Assessment of frozen semen}

\section{Thawing of semen straw}

Thawing of semen straw was carried out by immersing straw in warm water at $37{ }^{\circ} \mathrm{C}$ for 15 seconds [9].

\section{Post-thaw evaluation of frozen semen}

The membrane integrity of post-thaw semen was assessed by adding one drop of thawed semen mixed with solution was placed on warm stage slide covered with cover slip and observed under light microscope at $40 \mathrm{X}$ magnification as per technique used in cattle [7].

\section{Statistical analysis}

The analysis of variance (ANOVA) was applied to analyze the data. The data were presented in mean and standard error of mean. Least significant difference (LSD) test was applied where appropriate. 


\section{Results}

The study was conducted to evaluate the fresh and post thaw quality characteristics of Holstein Friesian bull semen. , for the period of three months. The bulls were maintained at semen production unit Quetta, Baluchistan. Twenty four semen samples were collected and utilized for this study. The results described as below:

Macroscopic characteristics of fresh semen

\section{Semen volume}

The mean $( \pm$ SEM $)$ ejaculated volume of semen from all four bulls were recorded as $7.103 \mathrm{ml}$ (Table 2). The semen volume was significantly $(\mathrm{P}<0.05)$ higher $(7.75 \mathrm{ml})$ when collected in the month of July and slightly decreased $(6.62 \mathrm{ml})$ in May. The mean ejaculate semen volume of Bull 1, 2, 3 and 4 shown non-significant difference ( $\mathrm{P}$ $>0.05$ ) between the bulls.

Table 2. Ejaculate mean $( \pm$ SEM) volume of Holstein Friesian bull semen

\begin{tabular}{|c|c|c|c|c|c|}
\hline Month of semen collection & $\begin{array}{c}\text { Bull-1 } \\
(\mathbf{m l})\end{array}$ & $\begin{array}{c}\text { Bull-2 } \\
(\mathbf{m l})\end{array}$ & $\begin{array}{c}\text { Bull-3 } \\
(\mathbf{m l})\end{array}$ & $\begin{array}{c}\text { Bull-4 } \\
(\mathbf{m l})\end{array}$ & $\begin{array}{c}\text { Mean }( \pm \text { SEM }) \\
(\mathbf{m l})\end{array}$ \\
\hline $1^{\text {st }} \cdot \& 2^{\text {nd }} \cdot$ week of May & 7.00 & 7.50 & 7.50 & 7.00 & $7.25 \pm 0.15^{\text {ab }}$ \\
\hline $3^{\text {rd }} \cdot \& 4^{\text {th }}$ week of May & 6.00 & 6.50 & 7.00 & 7.00 & $6.62 \pm 0.08^{\mathrm{b}}$ \\
\hline $1^{\text {st }} \cdot \& 2^{\text {nd }}$ week of June & 7.50 & 7.00 & 7.00 & 6.50 & $7.00 \pm 0.14^{\mathrm{b}}$ \\
\hline $3^{\text {rd }} \cdot \& 4^{\text {th }}$ week of June & 6.50 & 6.50 & 7.00 & 7.00 & $6.75 \pm 0.09^{\mathrm{b}}$ \\
\hline $1^{\text {st }} \cdot \& 2^{\text {nd }}$ week of July & 8.00 & 7.50 & 6.00 & 7.50 & $7.75 \pm 0.19^{\mathrm{a}}$ \\
\hline $3^{\text {rd }} \cdot \& 4^{\text {th }}$ week of July & 7.00 & 7.00 & 7.50 & 7.50 & $7.25 \pm 0.17^{\text {ab }}$ \\
\hline Mean & 7.00 & 7.00 & 7.33 & 7.08 & $7.103 \pm 0.14$ \\
\hline
\end{tabular}

P-value $>0.05,0.1390$

\section{Semen pH}

The mean $( \pm$ SEM $) \mathrm{pH}$ values of semen samples were recorded as 6.60 , collected from Holstein Friesian bulls. It was observed that the $\mathrm{pH}$ of semen was relatively higher (6.65) when collected in July, while a slight variation in semen $\mathrm{pH}$ was found, in May with semen $\mathrm{pH}$ of 6.62 and 6.55. The mean semen $\mathrm{pH}$ ejaculated from bull 1, 2, 3 and 4 was $6.58,6.62,6.67$ and 6.53 , respectively shown a nonsignificant $(\mathrm{P}>0.05)$ difference between the bulls (Table 3 ).

Table 3. Mean $( \pm$ SEM) PH of Holstein Friesian bull semen

\begin{tabular}{|c|c|c|c|c|c|}
\hline Month of semen collection & $\begin{array}{c}\text { Bull-1 } \\
(\mathbf{p H})\end{array}$ & $\begin{array}{c}\text { Bull-2 } \\
(\mathbf{p H})\end{array}$ & $\begin{array}{c}\text { Bull-3 } \\
(\mathbf{p H})\end{array}$ & $\begin{array}{c}\text { Bull-4 } \\
(\mathbf{p H})\end{array}$ & $\begin{array}{c}\text { Mean }(\mathbf{\pm S E M}) \\
(\mathbf{p H})\end{array}$ \\
\hline $1^{\text {st }} \cdot \& 2^{\text {nd }} \cdot$ week of May & 6.5 & 6.5 & 6.8 & 6.7 & $6.62 \pm 0.064$ \\
\hline $3^{\text {rd }} \cdot \& 4^{\text {th }}$ week of May & 6.5 & 6.7 & 6.5 & 6.5 & $6.55 \pm 0.045$ \\
\hline $1^{\text {st }} \cdot \& 2^{\text {nd }}$ week of June & 6.5 & 6.7 & 6.8 & 6.5 & $6.62 \pm 0.04$ \\
\hline $3^{\text {rd }} \cdot \& 4^{\text {th }}$ week of June & 6.8 & 6.5 & 6.5 & 6.5 & $6.57 \pm 0.19$ \\
\hline $1^{\text {st }} \cdot \& 2^{\text {nd }}$ week of July & 6.7 & 6.5 & 6.6 & 6.5 & $6.57 \pm 0.20$ \\
\hline $3^{\text {rd }} \cdot \& 4^{\text {th }}$ week of July & 6.5 & 6.8 & 6.8 & 6.5 & $6.65 \pm 0.018$ \\
\hline Mean & 6.58 & 6.62 & 6.67 & 6.53 & $6.60 \pm 0.074$ \\
\hline
\end{tabular}

P-value $>0.05,0.0571$

\section{Semen color}

The color of bull semen was observed creamy white in $62.50 \%$ of samples while the color of $37.50 \%$ samples were milky white. The results showed that irrespective of season of collection and age of bull, creamy white and milky white were the dominating color of semen collected from Holstein Friesian bulls (Table 4)

\section{Mass activity}

The mass activity of semen collected from May to July was in range of 3-4 score, with vigorous movement and moderate rapid 
waves and eddies to 4.00. The mean $( \pm$ SEM) mass activity was found higher (4.00), when semen collected in May and it was lower as 3.25, in month of July.
However, the difference in mass activity either between bulls or between ejaculates months were non-significant $(\mathrm{P}>0.05)$ (Table 5).

Table 4. Color of Holstein Friesian bull semen

\begin{tabular}{|c|c|c|c|c|}
\hline Month of semen collection & Bull-1 & Bull-2 & Bull-3 & Bull-4 \\
\hline $1^{\text {st }} \cdot \& 2^{\text {nd }} \cdot$ week of May & creamy white & creamy white & milky white & creamy white \\
\hline $3^{\text {rd }} \cdot \& 4^{\text {th }}$ week of May & creamy white & milky white & milky white & creamy white \\
\hline $1^{\text {st }} \cdot \& 2^{\text {nd }}$ week of June & milky white & milky white & milky white & creamy white \\
\hline $3^{\text {rd }} \cdot \& 4^{\text {th }}$ week of June & milky white & creamy white & creamy white & creamy white \\
\hline $1^{\text {st }} \cdot \& 2^{\text {nd }}$ week of July & creamy white & milky white & creamy white & creamy white \\
\hline $3^{\text {rd }} \cdot \& 4^{\text {th }}$ week of July & milky white & creamy white & creamy white & creamy white \\
\hline
\end{tabular}

P-value $>0.05,0.1552$

Table 5. Mean $( \pm$ SEM) mass activity of Holstein Friesian bull semen

\begin{tabular}{|c|c|c|c|c|c|}
\hline Month of semen collection & Bull-1 & Bull-2 & Bull-3 & Bull-4 & Mean $( \pm$ SEM $)$ \\
\hline $1^{\text {st }} \cdot \& 2^{\text {nd }}$. week of May & ++++ & ++++ & +++ & ++++ & $3.75 \pm 0.05$ \\
\hline $3^{\text {rd }} \cdot \& 4^{\text {th }}$ week of May & ++++ & ++++ & ++++ & ++++ & $4.00 \pm 0.06$ \\
\hline $1^{\text {st }} \cdot \& 2^{\text {nd }}$ week of June & +++ & ++++ & ++++ & ++++ & $3.75 \pm 0.57$ \\
\hline $3^{\text {rd }} \cdot \& 4^{\text {th }}$ week of June & +++ & ++++ & ++++ & ++++ & $3.75 \pm 0.054$ \\
\hline $1^{\text {st }} \cdot \& 2^{\text {nd }}$ week of July & ++++ & ++++ & +++ & ++++ & $3.75 \pm 0.057$ \\
\hline $3^{\text {rd }} \cdot \& 4^{\text {th }}$ week of July & +++ & ++++ & +++ & +++ & $3.25 \pm 0.048$ \\
\hline Mean & 3.5 & 4.00 & 3.50 & 3.83 & $3.6 \pm 0.052$ \\
\hline
\end{tabular}

P-value $>0.05$

Characteristics of fresh and post-thaw semen of Holstein Friesian bull Fresh and post-thaw sperm motility The mean $( \pm$ SEM) sperm motility of semen samples in fresh and post-thaw semen was recorded as $74.58 \%$ and $51.87 \%$ respectively in Holstein Friesian bull semen. The sperm motility of fresh vs postthaw semen was recorded obtained as 72.80 vs $48.75 \%, 75.00$ vs $48.75 \%, 76.25$ vs $55.00 \%, 73.75$ vs $52.50 \%, 75.00$ vs $56.25 \%$ and 75.00 vs $50.00 \%$ during the month of
May, June and July respectively. Analysis of variance showed non-significant effect of season on sperm motility. Fresh and post-thaw semen showed significant difference on sperm motility. In fresh semen the higher sperm motility was recoded as $76.25 \%$ in the month of June, while lower $72.80 \%$ in May of Holstein Friesian bull semen. In case of post-thaw semen, higher sperm motility of $56.25 \%$ was recorded in semen ejaculated in July, while lower $48.75 \%$ in May (Table 6).

Table 6. Mean ( \pm SEM) sperm motility $(\%)$ of fresh and post-thaw Holstein Friesian bull semen

\begin{tabular}{|c|c|c|}
\hline Month of semen collection & $\begin{array}{c}\text { Mean sperm motility of fresh } \\
\text { semen }(\boldsymbol{\%})\end{array}$ & $\begin{array}{c}\text { Mean sperm motility of post- } \\
\text { thaw semen }(\boldsymbol{\%})\end{array}$ \\
\hline $1^{\text {st }} \cdot \& 2^{\text {nd }} \cdot$ week of May & $72.80 \pm 1.32$ & $48.75 \pm 0.621$ \\
\hline $3^{\text {rd }} \cdot \& 4^{\text {th }}$ week of May & $75.00 \pm 3.39$ & $48.75 \pm 0.613$ \\
\hline $1^{\text {st }} \cdot \& 2^{\text {nd }}$ week of June & $76.25 \pm 2.87$ & $55.00 \pm 0.536$ \\
\hline $3^{\text {rd }} \cdot \& 4^{\text {th }}$ week of June & $73.75 \pm 1.64$ & $52.50 \pm 0.812$ \\
\hline $1^{\text {st }} \cdot \& 2^{\text {nd }}$ week of July & $75.00 \pm 3.62$ & $56.25 \pm 0.583$ \\
\hline $3^{\text {rd }} \cdot \& 4^{\text {th }}$ week of July & $75.00 \pm 3.18$ & $50.00 \pm 0.682$ \\
\hline Mean & $74.58 \pm 1.75$ & $51.87 \pm 0.648$ \\
\hline
\end{tabular}

P-value $>0.05,1.0567$ 


\section{Sperm concentration}

The higher sperm concentration was recorded as $1549.75 \times 10^{6}$ in semen ejaculated in month of June, followed by May $\left(1406.25 \times 10^{6}\right)$ and July $\left(1259.50 \times 10^{6}\right)$ in Holstein Friesian bull semen (Table 6). A significant difference in sperms concentration was found between the ejaculates.

Table 7. Mean $\left( \pm\right.$ SEM) sperm concentration $\left(\mathrm{x}^{\left.10^{6}\right)}\right.$ of Holstein Friesian bull semen

\begin{tabular}{|c|c|c|c|c|c|}
\hline $\begin{array}{c}\text { Month of semen } \\
\text { collection }\end{array}$ & Bull-1 & Bull-2 & Bull-3 & Bull-4 & Mean $( \pm$ SEM $)$ \\
\hline $1^{\text {st }} \cdot \& 2^{\text {nd }} \cdot$ week of May & $1290 \times 10^{6}$ & $1231 \times 10^{6}$ & $1302 \times 10^{6}$ & $1345 \times 10^{6}$ & $1292.00 \pm 12.37$ \\
\hline $3^{\text {rd }} \cdot \& 4^{\text {th }}$ week of May & $1455 \times 10^{6}$ & $1456 \times 10^{6}$ & $1360 \times 10^{6}$ & $1354 \times 10^{6}$ & $1406.25 \pm 9.84$ \\
\hline $1^{\text {st }} \cdot \& 2^{\text {nd }}$ week of June & $1491 \times 10^{6}$ & $1542 \times 10^{6}$ & $1432 \times 10^{6}$ & $1415 \times 10^{6}$ & $1470.00 \pm 11.48$ \\
\hline $3^{\text {rd }} \cdot \& 4^{\text {th }}$ week of June & $1629 \times 10^{6}$ & $1503 \times 10^{6}$ & $1552 \times 10^{6}$ & $1515 \times 10^{6}$ & $1548.75 \pm 12.31$ \\
\hline $1^{\text {st }} \cdot \& 2^{\text {nd }}$ week of July & $1444 \times 10^{6}$ & $1543 \times 10^{6}$ & $1460 \times 10^{6}$ & $1430 \times 10^{6}$ & $1469.25 \pm 8.93$ \\
\hline $3^{\text {rd }} \cdot \& 4^{\text {th }}$ week of July & $1218 \times 10^{6}$ & $1220 \times 10^{6}$ & $1250 \times 10^{6}$ & $1350 \times 10^{6}$ & $1259.50 \pm 16.26$ \\
\hline Mean & $1421.16 \times 10^{6}$ & $1415.83 \times 10^{6}$ & $1392.66 \times 10^{6}$ & $1401.50 \times 10^{6}$ & $1407.789 \pm 11.42$ \\
\hline
\end{tabular}

P-value $>0.05,24.1113$

\section{Membrane integrity}

The mean $( \pm$ SEM) membrane integrity of fresh semen was $58.37 \%$ against post-thaw $44.79 \%$. The membrane integrity in fresh semen was recorded as $60.75,57,58.75$, $57.50,56.25$ and $60 \%$ ejaculated in May, June and July respectively, while membrane integrity in post-thaw semen was 46.25 and $45.00,43.75$ and 42.50, 45.00 and $46.25 \%$ respectively in month of May, June and July (Table 8). It was found that the post-thaw membrane integrity of semen decreased considerably as compared to fresh semen.

Table 8. Mean $( \pm$ SEM) membrane integrity of fresh and post-thaw Holstein Friesian bull semen (HOT)

\begin{tabular}{|c|c|c|}
\hline Month of semen collection & $\begin{array}{c}\text { Membrane integrity of fresh } \\
\text { semen (\%) }\end{array}$ & $\begin{array}{c}\text { Membrane integrity of post- } \\
\text { thaw semen (\%) }\end{array}$ \\
\hline $1^{\text {st }} \cdot \& 2^{\text {nd }} \cdot$ week of May & $60.75 \pm 2.95$ & $46.25 \pm 0.873$ \\
\hline $3^{\text {rd }} \cdot \& 4^{\text {th }}$ week of May & $57.00 \pm 3 . .28$ & $45.00 \pm 0.649$ \\
\hline $1^{\text {st }} \cdot \& 2^{\text {nd }}$ week of June & $58.75 \pm 1.87$ & $43.75 \pm 0.771$ \\
\hline $3^{\text {rd }} \cdot \& 4^{\text {th }}$ week of June & $57.50 \pm 0.86$ & $42.50 \pm 0801$ \\
\hline $1^{\text {st }} \cdot \& 2^{\text {nd }}$ week of July & $56.25 \pm 2.26$ & $45.00 \pm 0924$ \\
\hline $3^{\text {rd }} \cdot \& 4^{\text {th }}$ week of July & $60.00 \pm 2.38$ & $46.25 \pm 0.692$ \\
\hline Mean & $58.37 \pm 1.53$ & $44.79 \pm 0.831$ \\
\hline
\end{tabular}

P-value $>0.05,0.987$

\section{Discussion}

Fresh and post thaw quality of Holstein Friesian bull semen were evaluated for volume, $\mathrm{pH}$, mass activity, sperm concentration, sperm motility and membrane integrity. Before discussing the results, few major points must be noted.

$1)$. the study was carried out in summer over a limited period i.e. May to July.

2). The member of available bulls was less i.e. 04 .

\section{Semen volume}

The findings of the present study showed that the ejaculate semen volume of Holstein Friesian bulls were recorded within the range of 6-8 $\mathrm{ml}$ and differences in ejaculates were significant $(\mathrm{P}<0.01)$. The volume was significantly $(\mathrm{P}<0.05)$ higher $(7.75 \mathrm{ml})$ when semen collected in month of July and slightly decreased $(6.62 \mathrm{ml})$ in May. The results of current study were in close agreement to the results $(7.4 \mathrm{ml})$ reported in local breeds of bulls in Bangladesh. In same study the volume of 
semen was reported as 9.8-12.8 $\mathrm{ml}$ in Holstein Friesian and crosses of Friesian [10], which were higher than the results recorded in current study. The results of present study also fall in similar trend as reported by others $[11,12]$. The results reported for the mean volume of semen as $4.92 \pm 0.23 \mathrm{ml}$ per ejaculate in Holstein Friesian cross and Zebu cattle $[10,11]$ were lower than the results of current study. The bulls of high fertility produced greater volume of semen than lower fertility bulls [13]. They further reported that the Holstein Friesian bulls produced less semen volume during summer season as compared to other seasons [14]. The ejaculate volume was reported significantly higher in Holstein Friesian and Jersey bulls during stress free and wet summer. However, contrast to above statement the season had no any significant effect on ejaculate volume in Holstein Friesian bulls [10, 15]. The differences in results might be attributed due to differences in breed of bull and environmental conditions. The bulls of the current study were very young. The discrepancy might be due to the breed or age of the bulls.

\section{Color}

In present study, most of the semen samples were creamy white and milky white in color. These results were in line with those of Zebu cattle $[15,16]$, that the color of semen was creamy white to milky white, but influenced by ambient temperature and humidity. Similar trend of results was also reported that the majority of the color of ejaculates was light creamy to dense creamy in all crossbred bulls, creamy color of semen was dominated by white and yellow [16]. These findings were in close matching to the observations recorded in present study. The difference in color of semen ejaculates also pertain to the type of breed, management and feed fed to the animals.

\section{Semen pH}

The mean $\mathrm{pH}$ of semen was recorded as 6.65 , it was higher when semen collected in the month of July and slightly lower (6.55) in May ejaculates. The results showed that the semen of Holstein Friesian bulls did not have considerable variation in $\mathrm{pH}$ from May to July. The results of current study were in close agreements with the results reported by others $[17,18]$. They reported that the mean $\mathrm{pH}$ of semen was $6.73 \pm 0.02$. The average $\mathrm{pH}$ before freezing was almost similar (6.4 to 6.5) for all breeds of bulls $[13,15]$. The results of current study for $\mathrm{pH}$ of semen fall in the same trend as reported in Holstein Friesian and cross of Zebu cattle semen, which varied from 6.1 to 6.5 . The results of present study were also supported by the results reported for Cross-bred, Sahiwal and Holsten Friesian bull semen [15]. The result of the current study indicated that the $\mathrm{pH}$ of semen did not markedly influenced due to breed variation. Normal pH of bull semen was 6.7. However when semen stored at room temperature may decreased the $\mathrm{pH}$ due to production of lactic acid from fructose. Semen $\mathrm{pH}$ may become alkaline when dead sperms percentage were high $[18,19]$. However variation in $\mathrm{pH}$ might be due to activity of sperms producing more lactic acid making semen acidic, but it was not within lethal level. The discrepancy might be due to breed variation and management patterns [13].

\section{Mass activity}

In current study the mass activity score of semen samples ejaculated showed vigorous movement with moderate to rapid waves and eddies. The mass motility of semen observed in present study was significantly lower ( $\mathrm{P}<0.05$ ) during wet summer (3.26) than dry summer (4.00). Individual motility in the semen of Holstein Friesian bulls not differ among seasons $(\mathrm{P}>0.05)$. The sperm motility of bull spermatozoa recorded in current study were in similar range to the results reported earlier in Holstein Friesian and Jersey bulls semen [20]. The results of the present study were in agreements with the findings of previous studies [21], they found significant changes in progressive motility of sperms at different semen collection times. The seasonal pattern for 
mass motility and individual motility of semen was different between the bulls and season of semen collection $[15,22]$. The results of present study were comparable with in the range of the above researchers $[15,20,22]$. The lower motility percentage was less than half as effective in producing optimum conception rate [20]. The motility of spermatozoa is one of the best evidence of viability. The results reported that no significant difference was found for fertility of semen containing 55 to $95 \%$ live sperms, however; semen containing less than $20 \%$ of live sperms were considered as infertile $[21,22]$. The results of current study indicates that the wet summer season deteriorates the semen quality in terms of mass motility of semen of Friesian bulls.

\section{Sperm concentration}

The sperm concentration is one of the most important criteria of semen characteristics to qualifying fertile male for breeding purpose. The ejaculated semen quality was examined for sperm concentration. The higher sperm concentration of $1548.75 \times 10^{6}$ was recorded in semen ejaculated in month of June and lower concentration $\left(1259.50 \times 10^{6}\right)$ in July. The sperm concentration is generally not associated with the season of semen collection, but it is generally associated with the breed, weight and the age of the bull. The sperms number per ejaculate differs significantly from bull to bull and within the bull [22]. The normal concentration of spermatozoa could be in the range of $150-200 \times 10^{6} / \mathrm{ml}$. These reported results are in matching with the results recorded in current study in Holstein Friesian bull semen. The results of current study were also in close agreements to the results reported in Zebu cattle [16, 22], that the initial motility and sperm concentration was significantly $(\mathrm{P}<0.05)$ higher during summer season than winter season. The initial motility and sperm concentration was higher in summer $(1193 \pm 52.2 \mathrm{million} / \mathrm{ml})$ and lower in winter season $(822.7 \pm 39.9 \mathrm{million} / \mathrm{ml})$ [21]. These results supports to the findings of the present study. In contrast to the results recorded in current study; that the higher sperms concentration were reported in spring and lowest in summer; the reported results indicates that the season had significant $(\mathrm{P}<0.05)$ effect on sperms concentration [22]. It was reported that the bull and season had significant effect on the semen volume, sperm concentration and sperm motility before and after freezing [23]. However, in contrast to that the season had no significant effect on sperm motility $[19,21]$. Sperm concentration could be considered as initial indicator of the quality of semen used for cryopreservation [23, 24].

\section{Post thaw assessment of semen}

The motility and plasma membrane integrity are important aspects to assess the fertility of sperms after freezing and thawing. In current study the post thaw motility and integrity of plasma membrane was studied to assess post thaw fertilizing ability of sperms.

\section{Sperm motility of fresh and post thaw semen}

The sperm motility was observed as markedly reduced after freezing and thawing as compared to fresh semen. The higher motility percentage was observed during the month of June, while lower during May in fresh and thawed semen. The mean sperm motility of semen samples over a period of three months in fresh semen was $74.58 \%$ against post-thaw sperm motility of $51.87 \%$. In case of post-thaw semen, higher sperm motility of $56.25 \%$ was recorded in semen ejaculated in July, while lower $48.75 \%$ in May. The results of the current study were in close agreements to the results reported in buffaloes [24]. Freezing and thawing of semen leads to decrease in percentage of intact sperms and reduces $50 \%$ viable sperms [15]. Whereas; it was reported that [25] the motility of semen averaged $45.9 \pm 5.2 \%$, which was lower than the findings recorded in current study in Holstein Friesian bull semen. The results of present study were lower than the results reported in Holstein Friesian, Sahiwal and their Crosses [15]. The sperms motility can 
be associated with better nutrition of bulls, breed as well as environmental temperature of the particular areas where the study is conducted.

\section{Membrane integrity test (HOT)}

The integrity of plasma membrane is one of the most important parameter, which is considered to be the key role in success of fertilization, when frozen semen is used. The membrane integrity of fresh semen samples was recorded as $58.37 \%$ against post-thaw semen as $44.79 \%$. The fertility of frozen-thawed bull semen was reduced by cryopreservation $[23,24]$. The semen of Sahiwal cow bull examined and reported that there were no significant difference in fresh and post-thaw motility of sperms [26]. The reported results were in contrast to the results of current study. This indicates that the semen from Holstein Friesian bull, freezes in similar pattern to those of other breeds of cattle reared in hot season [27, 28]. However, some contradictory reports were reported from different parts of the world. Such variation could be associated with the feeding regimes, bull breed, management and environmental factors.

\section{Conclusion}

The semen of Holstein Friesian bull was relatively higher volume,. The semen and $\mathrm{pH}$ did not significantly differ between bulls and ejaculates. Most of the semen samples were creamy white and milky white in color. Mass activity score of semen samples indicated vigorous movement with moderate rapid waves and eddies. Sperm motility was significantly affected in frozen and post-thaw semen. The semen of Holstein Friesian bull can tolerates freezing and thawing stress. The summer season has no significant adverse effect on quality of semen. The objective method of Osmotic Resistance Test was found to be useful parameter for assessment of in-vitro quality of the semen.

\section{Authors' contributions}

Conceived and designed the experiments: AH Baloch \& HK Kunbhar, Performed the experiments: AH Baloch, HK Kunbhar \& SM Sharif, Analysed the data: H Rizwana
\& ZI Rajput, Contributed materials/ analysis/ tools: MI Memon \& RA Leghari, Wrote the paper: AH Baloch \& HK Kunbhar.

\section{References}

1. Ax RL, Dally MR, Adidion B, Lienz RW, Love CC, Varner DD, Hafez B \& Bellin ME (2000). Artificial insemination in cattle. Reproduction in Farm Animals. ESE Hafez and B. Hafez. $7^{\text {th }}$ Ed. pp 21-19.

2. AWG (2008). Animal Husbandry Buffaloes. Reproductive Efficiency of Water Buffalo. Agriculture World Group, pp 1-3.

3. Hallap T, Jaakma U \& Martinez HR (2006). Changes in semen quality in Estonian Holstein AI bulls at 3, 5 and 7 years of age. Reprod Domest Anim 41(3): 214-8.

4. Dean J (2006). Semen and sperm quality. Department of Sexual Medicine, South Devon Health Care NHS Trust. pp 12-07.

5. Nico-Schhutto (2004). A working document of the rca project on improving animal productivity and reproductive efficiency Vienna, Austria, pp 22-4.

6. Hennery JB (1991). Clinical diagnosis and management by laboratory methods (18 ${ }^{\text {th }}$ Ed.), pp 499. Saunders Co.

7. Revel SG \& Mrode RA (1994). An osmotic resistance test for bovine semen. Ani Repr Sci 36 (1-2): 77-86.

8. Samad HA (1985). Proceeding of national workshop on processing of buffalo bull semen. pp.34 37. Agha jee Printers Rawalpindi.

9. Rasul Z, Anzarb M, Jualaia S \& Ahmed N (2000). Effect of buffering system on post-thaw motion characteristics, plasma membrane integrity, and acrosome morphology of buffalo spermatozoa. Ani Repr Sci 59(1-2): 28-31.

10. Mathevon M, Buhr MM \& Dekkers JCM (1998). Environmental, management, and genetic factors 
affecting semen production in Holstein bulls. J Dairy Sci 81: 3321-3330.

11. Hossain ME, Khatun MM, Islam MM \& Miazi OF (2012). Semen characteristics of breeding bulls at the Central Cattle Breeding and Dairy Farm of Bangladesh. Bangladesh $J$ Anim Sci 41(1): 1-5.

12. Koonjaenk SCV, Suneerat A, Tanu \& Heriberto R M (2007). Seasonal variation in semen quality of swamp buffalo bulls (Bubalus bubalis) in Thailand. Asian J Androl 9(1): 92-101.

13. Fuerst W, Hermann S, Christa $P$ \& Johann S (2006). Effects of age and environmental factors on semen production and semen quality of Austrian Simmental bulls. Animal Reprod Sci 95(2): 27-37.

14. Bhoite, UY, Sutar DA \& Ulmek BR (2008). Studies on semen quality of crossbred bulls. Indian Vet J 85: 395397.

15. Khan IM. Khan RU, Qureshi MS, Usman T, Khan A, Ullah Z \& Rehman H. 2018. Cross Breeding Promotes Deterioration of Semen Quality in Cattle Bulls. Pak J Zool 50(1): 97-103.

16. Kanchan \& Matharoo JS (2015). Effect of semen color on seminal characteristics in cattle bulls. Indian $J$ Anim Res 49(1): 146-14.

17. Anderson R (2004). Influence of $\mathrm{pH}$ on survival and fertility of bull sperm. $J$ Dairy Sc 7(5): 807-810.

18. Qureshi MS (2011). Preparation of semen extender, processing of semen and Storage. In: Reproductive physiology of domestic animals. Higher Education Commission, Islamabad, Pakistan, pp 127-129.

19. Sarder M Jalal-Uddin (2007). Environment related variations in the semen characteristics of bulls used for Artificial Insemination program in Bangladesh. Rajsh Uni Zool Soc 26: 81-88.

20. Fiaz M, Usmani R H, Abdullah M \& Ahmad T (2010). Evaluation of Semen
Quality of Holstein Friesian and Jersey Bulls Maintained under Subtropical Environment. Pak Vet J 30(2): 75-78.

21. Sarder MJU, Joarder OI \& Ali MS (2001). Semen production in relation to the age and season of Friesian cross and Sahiwal bulls for artificial insemination. J Biol Sci 9:39-46.

22. Kibria SS, Nahar TN, Mia MM \& Talukder AI (1997). Effect of genetic group, season and age of bull on semen characteristics. Bangladesh J Livestock Res 1-5: 92-102.

23. Leite TG, Filhoa VRV, Arrudab RP, Andrade AFC, Emericka LL, Zaffalonb FG \& Andre J (2010). Effects of extender and equilibration time on post-thaw motility and membrane integrity of cryopreserved Gyr bull semen evaluated by CASA and flow cytometry. Anim Reprod Sci 120: 31-38.

24. Zahid R, Ahmed N \& Anzar M (2007). Changes in motion characteristics, plasma membrane integrity and acrosome morphology during cryopreservation of buffalo spermatozoa. J Androl 22:2.

25. Lessard C, Parent S, Leclerc P, Bailey J L \& Sullivan R (2008). Cryopreservation alters the levels of the bull sperm surface protein P25b. $J$ Androl 21(5): 700-707.

26. Andrabi SMH, Ahmad N, Abbas A \& Anzar M (2009). Effect of two different antibiotic combinations on fertility of frozen buffalo and Sahiwal bull semen. Pak J Biol Sci 11(4): 13281335.

27. Patel BR \& Siddiquee GM (2013) Physical and morphological characteristics of Kankrej bull semen. Vet World 6(7): 405-408.

28. Hussain SS, Ahmed A, Mostafa KG \& Bhuiyan AKFH (1985). Effect of season on semen characteristics of crossbred bulls under field conditions. Bangladesh J Anim Sci 14: 18-22. 